\title{
Kebijakan Perlindungan Sosial Indonesia pada Situasi Krisis Corona Virus Disease 2019
}

\section{Indonesia's Social Protection Policy in the 2019 Corona Virus Disease Crisis Situation}

\author{
Heri Nugroho' ${ }^{1}$ Zulfa Ruhama
}

1,2 Kementerian Koordinator Bidang Pembangunan Manusia dan Kebudayaan

\section{Penulis Korespondensi}

Zulfa Ruhama

zulfairy@yahoo.com

+6282111702199

\begin{abstract}
Abstrak
Penelitian ini bertujuan untuk menganalisis perubahan kebijakan perlindungan sosial di Indonesia di masa krisis pandemi Corona Virus Disease 2019 (Covid-19). Pandemi Covid-19 berdampak pada krisis ekonomi yang terjadi baik di negara maju maupun negara berkembang. Kebijakan pembatasan mobilitas manusia menjadi hal yang perlu dilakukan untuk mengurangi kerugian yang lebih besar. Hal ini membuat pemanfaatan teknologi menjadi semakin intens untuk menjaga peran welfare state dan sistem perlindungan sosial yang lebih baik di Indonesia. Penelitian ini bertujuan untuk memahami perubahan sistem perlindungan sosial yang diterapkan sebagai respons dari pandemi Covid-19. Metode yang digunakan yaitu pendekatan kualitatif eksploratif. Studi ini menghasilkan tiga temuan penting. Pertama, Indonesia telah memiliki berbagai program perlindungan sosial yang dibangun dari sejak krisis pada 1998 dan terus dikembangkan hingga saat pandemi Covid-19. Kedua, Indonesia telah menjalankan peran negara kesejahteraan dengan melakukan dan mengendalikan kombinasi strategi perlindungan sosial yang mencakup kombinasi perluasan bantuan sosial, pengembangan program bantuan sosial, penambahan program bantuan sosial, dan penataan ulang program bantuan sosial sebagai respons dari krisis Covid-19. Ketiga, kekhususan karakteristik dari krisis akibat pandemi Covid-19 telah mengubah sistem perlindungan sosial Indonesia menjadi lebih banyak dan beragam, pelebaran defisit anggaran untuk mengakomodasi peningkatan anggaran bantuan sosial dan pemulihan ekonomi nasional, serta penggunaan teknologi untuk pemutakhiran basis data dan penyaluran perlindungan sosial yang lebih tepat sasaran.
\end{abstract}

\section{Kata Kunci}

perlindungan sosial; negara kesejahteraan; pandemi Covid-19

\begin{abstract}
This study aims to analyze changes in social protection policies in Indonesia during the Covid-19 pandemic crisis. The Covid-19 pandemic has had an impact on the economic crisis, which has occurred in both developed and developing countries. The policy of limiting human mobility is something that needs to be done to reduce greater losses. This makes the use of technology increasingly intense to maintain the role of the welfare state and a better social protection system in Indonesia. This study aims to understand the changes in the social protection system implemented in response to the Covid-19 pandemic. The method used is exploratory qualitative approach. This study yielded three important findings. First, Indonesia has had various social protection programs built since the 1998 crisis and continued to be developed until the Covid-19 pandemic. Second, Indonesia has carried out the role of the welfare state by implementing and controlling a combination of social protection strategies that include a combination of expanding social assistance, developing social assistance programs, adding social assistance programs, and restructuring social assistance programs in response to the Covid-19 crisis. Third, the specific characteristics of the Covid-19 pandemic have changed Indonesia's social protection system to become more numerous and varied, widening the budget deficit to accommodate an increase in the social assistance budget and national economic recovery, as well as the use of technology for updating databases and distributing social protection more accurately.
\end{abstract}

\section{Keywords}

social protection; welfare state; Covid-19 pandemic 


\section{Pendahuluan}

Pandemi Covid-19 telah membawa krisis multidimensi di banyak negara di dunia. Bank Dunia memperkirakan bahwa kemiskinan ekstrem akan meningkat mencapai 150 juta orang pada tahun 2021 karena pandemi Covid-19 (World Bank, 2020c). Jurang kesenjangan pendapatan antara yang kaya dan miskin sendiri telah menunjukkan kenaikan bahkan sebelum pandemi Covid-19 berlangsung (Department of Economic and Social Affairs, 2020, hlm. 3-4). Penelitian terbaru menunjukkan kalangan rentan yang paling terdampak dari semakin timpangnya kesenjangan ini adalah perempuan dan anak-anak (Carli, 2020, hlm. 651-652). Pandemi Covid-19 juga terindikasi akan meniadakan capaian kemajuan pembangunan manusia yang telah diupayakan bertahuntahun sebelumnya. Pemerintah di banyak negara di dunia menghadapi tantangan yang kompleks karena bukan hanya harus berhadapan dengan naiknya angka kemiskinan tetapi juga ancaman kesehatan masyarakat.

Perlindungan sosial yang harus diberikan pemerintah saat krisis pandemi Covid-19 bukanlah perlindungan sosial biasa. Pada saat krisis ekonomi, welfare state ditantang untuk mengamankan dan memenuhi hak dan kebutuhan warganya seperti hak atas pelayanan kesehatan, layanan pendidikan gratis, bantuan atau tunjangan dan jaminan sosial (Barr, 2020, hlm. 38-40). Core business welfare state yang merupakan pemberian dukungan untuk mendukung kelompok yang mengalami kerentanan dan kehilangan mata pencaharian dengan cara memberi uang, materi, atau barang. Pada saat krisis, welfare state memiliki fungsi sebagai automatic stabilizer atau penyeimbang keadaan otomatis agar kesejahteraan masyarakat tidak semakin terpuruk. Fungsi sosial suatu negara bagi kelompok rentan selalu diperdebatkan dan secara politis pertanyaan akan fungsi sosial negara terhubung dengan munculnya konsep welfare state. Memberikan kesejahteraan bagi penduduknya merupakan kegiatan moral dan nilai-nilai yang berlandaskan nilai-nilai masyarakat di mana negara tersebut beroperasi dan merupakan suatu kewajiban welfare state untuk terus berkembang atau adaptif menyesuaikan kondisi terkini (Christos dkk., 2019, hlm. 4).

Konsep welfare state sendiri secara sederhana dapat dipahami sebagai suatu kompilasi kebijakan sosial di mana terdapat berbagai mekanisme perlindungan kesejahteraan masyarakat dari mekanisme pasar. Lebih spesifik lagi, welfare state mengacu pada suatu sektor yang diurus atau dikelola oleh negara (Wincott, 2001, hlm. 409). Pendekatan lain yang paling banyak digunakan untuk mengukur apakah suatu negara merupakan welfare state adalah "upaya menyejahterakan" yang dilakukan oleh negara tersebut. Upaya suatu negara untuk mencapai kesejahteraan ini mengacu pada jumlah pengeluaran negara yang didedikasikan untuk fungsifungsi sosial, seperti bantuan sosial, jaminan kesehatan, atau jaminan pensiun. Dalam pandangan ini, negara yang mencurahkan pendapatan nasionalnya untuk transfer-transfer sosial, meskipun secara implisit, didefinisikan sebagai memiliki upaya kesejahteraan untuk masyarakatnya.

Identifikasi operasionalisasi welfare state dapat juga diukur dengan program perlindungan sosial yang telah diadopsi suatu negara dalam peraturan perundang-undangan. Menurut Suharto (2011, hlm. 2-3), secara umum yang dimaksud dengan perlindungan sosial yaitu kumpulan upaya publik yang dilakukan dalam menghadapi dan menanggulangi kerentanan, risiko dan kemiskinan yang sudah melebihi batas bagi kelompok rentan. Perlindungan sosial merupakan konsep yang lebih luas dari jaminan sosial, lebih luas dari asuransi sosial, dan jejaring pengaman sosial. Saat ini sebagian besar definisi operasional tentang welfare state ditentukan oleh serangkaian intervensi legislatif di bidang jaminan sosial (pensiun, pelayanan kesehatan), kepedulian sosial (untuk anak-anak, lansia, dan rakyat miskin), tunjangan sosial (perumahan, pelatihan kerja), serta perlindungan tenaga kerja dan perlindungan terhadap pengangguran (Morlino \& Raniolo, 2017, hlm. 23).

Semua prinsip dan ciri welfare state tersebut telah dikukuhkan dalam berbagai peraturan perundang-undangan di Indonesia. Cita-cita Indonesia sebagai welfare state telah tertuang dalam pembukaan UUD Negara Republik Indonesia Tahun 1945, di mana 'memajukan kesejahteraan umum' yang tercantum dalam alinea pembukaan tersebut dapat dimaknai sebagai peran negara untuk memberikan program-program kesejahteraan secara universal, adil dan merata kepada semua warga Indonesia (Iping, 2020, 518). Program-program perlindungan sosial di Indonesia diatur secara terpisah dalam berbagai peraturan perundang-undangan antara lain UndangUndang Nomor 6 Tahun 2014 tentang Desa yang mengamanatkan Dana Desa, Peraturan Pemerintah Nomor 75 Tahun 2015 tentang Perubahan Peraturan Pemerintah Nomor 101 Tahun 2012 tentang Penerima Bantuan Iuran Peraturan Menteri Sosial Nomor 1 Tahun 2018 tentang Program Keluarga Harapan. Disisi lain, untuk program jaminan sosial didasari oleh Sistem Jaminan Sosial Nasional (SJSN) yang dikukuhkan melalui Undang-Undang Nomor 40 Tahun 2004. Kemudian UU Nomor 24 Tahun 2011 tentang Badan Penyelenggara Jaminan Sosial Nasional (UU BPJS) yang menjadi dasar hukum pembentukan badan penyelenggara jaminan sosial, yaitu BPJS Kesehatan dan BPJS Ketenagakerjaan.

Perkembangan perlindungan sosial di Indonesia ditinjau dari sudut pandang welfare state menurut Sumarto (2017, hlm. 952-953) dapat dikategorikan menjadi 4 periode yaitu (i) 1945-1966 yang merupakan periode rawan/precarious welfare regime, (ii) periode tahun 1966-1998 yang merupakan periode produktivis/productivist welfare regime, (iii) periode informal liberal/informal-liberal welfare regime pada tahun 1998-2014 yang ditandai dengan krisis ekonomi Asia dan UU BPJS, serta (iv) periode 2014-seterusnya yang disebut sebagai periode transisi menuju periode informalinklusif/informal-inclusive welfare regime dengan pelembagaan sistem jaminan kesehatan semesta di Indonesia. 
Kebijakan Perlindungan Sosial Indonesia

Tabel 1. Program Perlindungan Sosial di Indonesia sejak Sebelum Pandemi Covid-19

\begin{tabular}{|c|c|c|c|}
\hline Nama Program & Tujuan & Manfaat/Cakupan & Institusi Pengampu \\
\hline $\begin{array}{l}\text { Program Keluarga } \\
\text { Harapan (PKH) }\end{array}$ & $\begin{array}{l}\text { Pengurangan angka } \\
\text { kemiskinan }\end{array}$ & 9.2 Juta Keluarga (2019) & Kementerian Sosial \\
\hline $\begin{array}{l}\text { Program Indonesia Pintar } \\
\text { (PIP) }\end{array}$ & $\begin{array}{l}\text { Biaya sekolah terjangkau, } \\
\text { program lanjutan dari } \\
\text { Bantuan Siswa Miskin } \\
\text { (BSM) }\end{array}$ & 16,18 Juta Siswa (2020) & $\begin{array}{l}\text { Kementerian Pendidikan } \\
\text { dan Kebudayaan dan } \\
\text { Kementerian Agama }\end{array}$ \\
\hline $\begin{array}{l}\text { Program Sembako/ } \\
\text { Bantuan Pangan Non } \\
\text { Tunai (BNPT) }\end{array}$ & $\begin{array}{l}\text { Ketahanan pangan dan } \\
\text { nutrisi }\end{array}$ & 19,4 Juta KPM (2020) & Kementerian Sosial \\
\hline $\begin{array}{l}\text { Penerima Bantuan luran } \\
\text { Jaminan Kesehatan (PBI } \\
\text { JKN) }\end{array}$ & $\begin{array}{l}\text { Perlindungan kesehatan } \\
\text { bagi fakir miskin }\end{array}$ & 96,7 Juta Jiwa (2020) & $\begin{array}{l}\text { BPJS Kesehatan dan } \\
\text { Kementerian Kesehatan }\end{array}$ \\
\hline $\begin{array}{l}\text { Program Beasiswa } \\
\text { Pendidikan bagi } \\
\text { Masyarakat Miskin } \\
\text { (Bidikmisi) }\end{array}$ & $\begin{array}{l}\text { Program bantuan bagi } \\
\text { siswa dari keluarga yang } \\
\text { tidak mampu yang telah } \\
\text { memiliki Kartu Indonesia } \\
\text { Pintar (KIP-Kuliah) }\end{array}$ & 130 ribu penerima (2019) & $\begin{array}{l}\text { Kementerian Riset, } \\
\text { Teknologi dan Pendidikan } \\
\text { Tinggi }\end{array}$ \\
\hline Subsidi Tarif Listrik & $\begin{array}{l}\text { Bantuan keringanan biaya } \\
\text { listrik untuk pelanggan }\end{array}$ & $\begin{array}{l}\text { Subsidi untuk tarif } 450 \text { VA } \\
\text { dan } 900 \text { VA (miskin) }\end{array}$ & Kementerian ESDM \\
\hline Jaminan Kesehatan (JKN) & $\begin{array}{l}\text { Memberikan manfaat } \\
\text { pemeliharaan kesehatan } \\
\text { dan perlindungan akan } \\
\text { pemenuhan kebutuhan } \\
\text { dasar masyarakat }\end{array}$ & $\begin{array}{l}\text { 223,9 juta jiwa, (Per Mei } \\
\text { 2021) }\end{array}$ & BPJS Kesehatan \\
\hline $\begin{array}{l}\text { Jaminan Kecelakaan Kerja } \\
\text { (JKK) }\end{array}$ & $\begin{array}{l}\text { Memberikan } \\
\text { perlindungan atas risiko } \\
\text { kecelakaan yang terjadi } \\
\text { dalam hubungan kerja }\end{array}$ & 31,6 juta jiwa, (2020) & BPJS Ketenagakerjaan \\
\hline Jaminan Hari Tua (JHT) & $\begin{array}{l}\text { Menjamin agar peserta/ } \\
\text { pekerja menerima uang } \\
\text { tunai apabila memasuki } \\
\text { masa pensiun, mengalami } \\
\text { cacat total tetap, atau } \\
\text { meninggal dunia }\end{array}$ & 36,4 juta jiwa, (2020) & BPJS Ketenagakerjaan \\
\hline Jaminan Kematian & $\begin{array}{l}\text { Memberikan } \\
\text { santunan kematian yang } \\
\text { dibayarkan kepada ahli } \\
\text { waris peserta/pekerja } \\
\text { yang meninggal dunia }\end{array}$ & 31,6 juta jiwa, (2020) & BPJS Ketenagakerjaan \\
\hline Jaminan Pensiun & $\begin{array}{l}\text { Mempertahankan derajat } \\
\text { kehidupan yang layak } \\
\text { bagi peserta dan/atau ahli } \\
\text { warisnya dengan } \\
\text { memberikan penghasilan } \\
\text { setelah peserta memasuki } \\
\text { usia pensiun, mengalami } \\
\text { cacat total tetap, atau } \\
\text { meninggal dunia }\end{array}$ & 16,3 juta jiwa, (2020) & BPJS Ketenagakerjaan \\
\hline
\end{tabular}

Sumber: Data olahan penulis berdasarkan data dari Kementerian Sosial dan Kementerian Keuangan tahun 2020, BPJS Kesehatan dan BPJS Ketenagakerjaan dan dokumen ringkasan kebijakan TNP2K

Perubahan kebijakan terkait perlindungan sosial di Indonesia dari tiap periode tersebut dipicu oleh pertumbuhan ekonomi, tekanan pasar global dan 'universalisasi' kebijakan sosial. Indonesia telah mengalami berbagai krisis ekonomi dari skala kecil sampai besar seperti krisis moneter tahun 1998, dan respons pemerintah pada setiap krisis selalu mengandalkan kebijakan sosial. Akselerasi reformasi menuju sistem perlindungan sosial sepanjang hayat dan andal melalui integrasi data dan program yang adaptif dari tahun ke tahun juga terus menjadi program prioritas pemerintah. Bantuan Sosial (Bansos) hadir pada saat krisis moneter 1998, Bantuan
Langsung Tunai (BLT) (tahun 2004), Program Keluarga Harapan (PKH) (tahun 2007), dan UU SJSN yang menjadi dasar jaminan sosial bagi semua warga (tahun 2004). Sebelum pandemi Covid-19, program perlindungan sosial di Indonesia dapat dilihat pada Tabel 1 .

Perlahan namun pasti Indonesia telah membentuk sistem perlindungan sosial. Sehingga, sejak era reformasi Indonesia telah memiliki pengalaman dan kemampuan mengelola perlindungan sosial di masa krisis. Anggaran belanja pemerintah yang direalisasikan pada belanja subsidi, belanja bantuan sosial, dan belanja bantuan dari tahun 2006-2017 juga 
memiliki hubungan yang kuat dengan beberapa variabel indikator kesejahteraan antara lain persentase pendidikan, persentase penduduk miskin, dan persentase rumah tangga (Uluwiyah, 2018, hlm. 316).

Penelitian yang mengupas mengenai sistem perlindungan sosial di saat krisis Covid-19 di Indonesia tengah menjadi perhatian banyak pihak karena hingga saat tulisan ini dibuat (Juni 2021) krisis Covid-19 yang memicu perubahan sistem perlindungan sosial di banyak negara di dunia masih belum dinyatakan selesai. Lebih dari 100 negara di dunia yang menghadiri World Health Assembly ke-74 tanggal 29 Mei 2021 dan menandatangani resolusi kesehatan yang menyoroti kebutuhan mendesak untuk meningkatkan kapasitas produksi obat-obatan lokal dan teknologi kesehatan lainnya yang berkualitas di seluruh dunia. Secara khusus, resolusi WHO juga menyerukan agar semua pemerintahan di dunia menerapkan strategi yang lebih komprehensif, menyusun rencana aksi nasional, lingkungan bisnis yang kondusif, pengembangan sumber daya manusia, kolaborasi dengan berbagai pemangku kepentingan, serta menguatkan jejaring Internasional untuk melalui krisis pandemi Covid-19.

Beberapa penelitian menyoroti hubungan antara Indonesia sebagai negara kesejahteraan dan kebijakan perlindungan sosial yang diambil ketika krisis Covid-19, penelitian lainnya mendalami berbagai jenis bantuan sosial yang disalurkan saat krisis, mekanisme penyaluran bantuan sosial dan masalah yang dihadapi dalam penyaluran bantuan sosial tersebut. Akan tetapi, belum banyak penelitian yang secara menyeluruh menganalisis bagaimana kekhususan karakteristik pandemi Covid-19 telah mempengaruhi kebijakan dan penerapan sistem perlindungan sosial di Indonesia. Peneliti mengangkat topik ini dalam penelitian untuk memperoleh pemahaman yang lebih komprehensif tentang bagaimana kekhususan karakteristik krisis akibat pandemi Covid-19 mempengaruhi kebijakan perlindungan sosial di Indonesia dengan bersandar pada kerangka analisis welfare state.

\section{Metode}

Penelitian ini akan menggunakan pendekatan kualitatif secara eksploratif. Definisi penelitian kualitatif adalah pendekatan penelitian yang berupaya menelusuri dan mengeksplorasi suatu masalah atau fenomena sentral dengan tujuan untuk dapat memahaminya (Creswell dkk., 1996). Pendekatan penelitian kualitatif secara eksploratif dipilih oleh peneliti karena isu sistem perlindungan sosial dalam krisis Covid-19 membutuhkan pemetaan kasus yang melibatkan eksplorasi dan penelusuran intensif dari berbagai sumber serta analisis atas data-data tersebut untuk menghasilkan sebuah kesimpulan naratif. Peneliti akan mengeksplorasi kompleksitas perlindungan sosial saat krisis Covid-19 di Indonesia dengan bersandar pada konsep welfare state karena corak khas dari pandemi Covid-19 yang menggabungkan kedaruratan di bidang ekonomi dan kesehatan masyarakat pada level global.

\section{Hasil dan Pembahasan}

WHO mendeklarasikan wabah Covid-19 sebagai kedaruratan kesehatan masyarakat yang meresahkan dunia atau Public Health Emergency of International Concern/PHEIC pada Januari 2020 yang kemudian ditingkatkan statusnya sebagai pandemi global pada 11 Maret 2020. Penyebaran Covid-19 telah mencapai tingkat yang mengkhawatirkan di berbagai negara hingga WHO menyerukan negara-negara untuk meningkatkan keseriusan mereka dalam menanggulangi ancaman Covid-19. Berbeda dengan pandemi atau krisis sebelumnya, kekhususan pandemi Covid-19 karena kejadian ini terjadi dalam skala global. Dibandingkan dengan wabah sebelumnya seperti Ebola di Afrika Selatan dan Malawi atau Severe Acute Respiratory Syndrome (SARS) yang terjadi di Asia, pandemi Covid-19 tidak terkonsentrasi pada wilayahwilayah tertentu. Pandemi Covid-19 berdampak pada hampir semua negara maju maupun berkembang, serta memakan banyak korban dan menyebabkan krisis ekonomi yang berkepanjangan, juga banyak bersinggungan dengan teknologi karena adanya pembatasan sosial dalam skala tertentu hingga penyaluran bantuan sosial maupun intervensi kesehatan masyarakat dilakukan secara non-fisik, melalui rekening bank penerima atau alat pembayaran digital. Peran negara sebagai stabilisator banyak dituntut saat krisis akibat pandemi Covid-19, bila dibandingkan dengan saat pandemi Ebola atau AIDS di mana lembaga internasional dan institusi nonpemerintah memainkan lebih banyak peran. Perluasan dan peningkatan ragam program perlindungan sosial sebagai respons atas Covid-19 lebih banyak dilaksanakan dan dikendalikan oleh pemerintah (Abdoul-Azize \& El Gamil, 2021, hlm. 114).

Penelitian yang terus berlangsung/living documents yang dilakukan Gentilini dkk. (2020, hlm. 4-5) untuk World Bank menemukan bahwa antara Maret 2020 sampai dengan Mei 2021 sebanyak 222 negara di seluruh dunia telah menerapkan 3.333 program perlindungan sosial untuk merespons pandemi Covid-19. Di Asia Selatan dan negara berpenghasilan menengah ke bawah lainnya, mayoritas program yang digulirkan adalah bantuan sosial. Sebanyak $42 \%$ atau 734 program dari program perlindungan sosial yang telah direncanakan atau diterapkan di 186 negara adalah skema bantuan tunai dengan 69\% dari 734 skema tersebut merupakan skema baru. Sejak Maret 2020, meningkatnya kesenjangan dan berbagai perubahan drastis akibat krisis Covid-19 telah memungkinkan percepatan penerapan beberapa program perlindungan sosial yang sebelum pandemi sulit diimplementasikan negara karena pertimbangan politis (Patel \& Kariel, 2021, hlm. 1).

Terlepas dari perbedaan fitur sosial dan ekonomi suatu negara, kebijakan perlindungan sosial telah menjadi salah satu strategi utama dalam menghadapi pandemi Covid-19. Hal ini sejalan dengan penelitian Breznau (2021, hlm. S43-S44) di 70 negara pada April 2020 yang menemukan bahwa persepsi risiko publik mempengaruhi intervensi program kesejahteraan masyarakat dari negara dalam krisis akibat pandemi. Ketika 
Gambar 1. Jumlah Penduduk Miskin pada September 2020

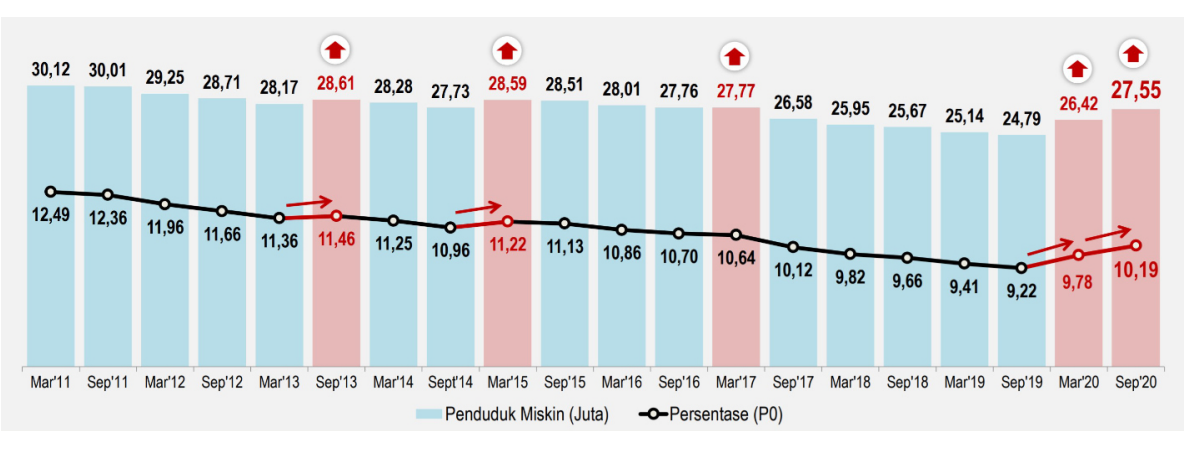

Sumber: Badan Pusat Statistik persepsi risiko publik mengenai intervensi negara dalam merespons pandemi Covid-19 gagal atau kurang tepat, program-program kesejahteraan welfare state menjadi kebijakan selanjutnya. Tidak hanya negara berpenghasilan menengah ke bawah yang menerapkan sistem perlindungan sosial untuk menghadapi krisis pandemi Covid-19, namun juga negara menengah ke atas seperti Amerika, Inggris, Jerman, dan Spanyol, meski fokus kedua jenis negara tersebut berbeda. Negara berpenghasilan menengah ke atas berfokus pada penerapan perlindungan sosial untuk tujuan jangka panjang seperti menstabilkan dampak ekonomi makro dari pandemi, sementara negara berpenghasilan menengah ke bawah cenderung berfokus tujuan jangka pendek yaitu jaring pengaman sosial bagi masyarakat miskin selama pandemi Covid-19 (Abdoul-Azize \& El Gamil, 2021, hlm. 114).

Jumlah masyarakat Indonesia yang berhak menerima bantuan sosial dan perlindungan sosial bertambah dari yang telah ditargetkan oleh pemerintah karena krisis Covid-19. Pada kuartal pertama tahun 2020, persentase penduduk miskin adalah 9,78 persen, naik 0,37 persen bila dibandingkan angka kemiskinan pada Maret 2019. Persentase penduduk miskin di perdesaan naik 0,6 persen menjadi 13,20 pada September 2020 dari September 2019. Di perkotaan, persentase penduduk miskin perkotaan naik menjadi 7,88 dari 6,56 pada September 2019 (Purwanto, 2021). Dalam simulasi yang dilakukan Suryahadi dkk. (2020, hlm. 188) untuk memprediksikan tingkat kemiskinan dan pertumbuhan ekonomi karena pandemi Covid-19, diperkirakan bahwa angka kemiskinan meningkat sampai dengan $16,6 \%$ atau sebanyak 19,7 juta jiwa masyarakat miskin bila pertumbuhan ekonomi mencapai angka $-3,2 \%$. Namun tingkat kemiskinan Indonesia melampaui angka tersebut dan terus meningkat (Gambar 1).

Akibat pandemi Covid-19, tingkat kemiskinan nasional terus naik dari $9,78 \%$ menjadi $10,19 \%$, jumlah penduduk miskin pada bulan September 2020 sebesar 27,55 juta orang $(10,19 \%)$, naik 1,13 juta orang $(0,41 \%)$ terhadap Maret 2020 dan naik 2,76 juta orang (0,97\%) terhadap September 2019. Kenaikan jumlah penduduk miskin menjadi 27,55 juta orang di tahun 2020 dari total penduduk sebesar 270,2 juta menurut (World Bank, 2020a) menandai hilangnya tiga tahun capaian Indonesia dalam upaya mengurangi kemiskinan. Implikasi dari tingginya kenaikan angka kemiskinan ini adalah urgensi perluasan sistem perlindungan sosial yang menyasar kelompok rentan baru selain juga tetap melindungi penerima manfaat yang lama.

Ditinjau dari sisi penganggaran, dari tahun ke tahun Indonesia secara konsisten telah mengalokasikan anggaran untuk program perlindungan sosial. Demikian juga alokasi anggaran belanja fungsi perlindungan sosial terus meningkat dari 2016-2021. Pada tahun 2020, sebagai upaya penanggulangan Covid-19 di Indonesia belanja perlindungan sosial melonjak menjadi 250,7 triliun rupiah (Gambar 2). Belanja tersebut antara lain dimanfaatkan untuk memperluas cakupan program bantuan sosial dan menaikkan indeks bantuan. Beberapa komponen perlindungan sosial yang mengalami kenaikan antara lain penerima manfaat Program Bantuan Sembako diperluas menjadi 20 juta KPM dari sebelumnya 19 juta KPM, serta indeks bantuan Program
Gambar 2. Perkembangan Belanja Fungsi Perlindungan Sosial, 2016-2021

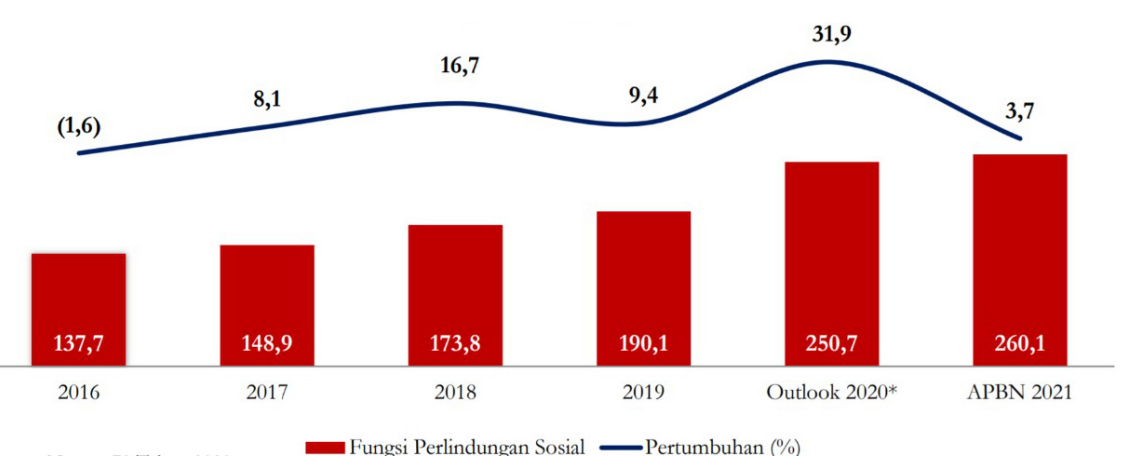

Sumber: Nota Keuangan Kementerian Keuangan 2016-2021, data diolah 
Tabel 2. Perubahan dan Perkembangan Perlindungan Sosial Setelah Pandemi Covid-19

\begin{tabular}{|c|c|c|c|}
\hline No. & Nama Program & Jenis Program & Keterangan \\
\hline 1 & $\begin{array}{l}\text { Program Keluarga } \\
\text { Harapan }\end{array}$ & $\begin{array}{l}\text { Pengembangan program } \\
\text { bantuan sosial }\end{array}$ & $\begin{array}{l}\text { - Penerima meningkat menjadi } 10 \text { juta } \\
\text { KPM } \\
\text { - Telah tersalurkan Rp } 29,133 \text { triliun dan } \\
\text { sudah diterima oleh } 10 \text { juta penerima } \\
\text { manfaat } \\
\text { - Frekuensi penyaluran menjadi setiap } \\
\text { bulan selama masa pandemi Covid-19 } \\
\text { yang sebelumnya secara triwulan }\end{array}$ \\
\hline 2 & Program Kartu Sembako & $\begin{array}{l}\text { Pengembangan program } \\
\text { bantuan sosial yang } \\
\text { sudah ada }\end{array}$ & $\begin{array}{l}\text { - Telah tersalurkan } \mathrm{Rp} 30,978 \text { triliun dan } \\
\text { sudah diterima 19,41 juta penerima } \\
\text { manfaat }\end{array}$ \\
\hline 3 & Subsidi Tarif Listrik & $\begin{array}{l}\text { Pengembangan program } \\
\text { bantuan sosial yang } \\
\text { sudah ada }\end{array}$ & $\begin{array}{l}\text { - Tarif } 450 \text { VA digratiskan dan Tarif } 900 \text { VA } \\
\text { diberikan diskon } 50 \% \\
\text { - Telah tersalurkan Rp 3,455 triliun, sudah } \\
\text { diterima 31,4 juta penerima subsidi listrik } \\
\text { - 32,1 Juta Pelanggan (RT dan UMKM 2020) }\end{array}$ \\
\hline 4 & $\begin{array}{l}\text { Program Bantuan } \\
\text { Sembako di Jabodetabek }\end{array}$ & $\begin{array}{l}\text { Pengembangan program } \\
\text { bantuan sosial dengan } \\
\text { pelibatan pemerintah } \\
\text { daerah }\end{array}$ & $\begin{array}{l}\text { - Telah tersalurkan Rp4,407 triliun dan } \\
\text { sudah diserahterimakan kepada 1,9 juta } \\
\text { penerima manfaat }\end{array}$ \\
\hline 5 & $\begin{array}{l}\text { Program Subsidi Gaji/ } \\
\text { Upah }\end{array}$ & $\begin{array}{l}\text { Perluasan Sistem Jaminan } \\
\text { Sosial }\end{array}$ & $\begin{array}{l}\text { - Program baru, baru kali ini } \\
\text { diselenggarakan di Indonesia, menyasar } \\
\text { 13-15 juta pekerja } \\
\text { - Telah tersalurkan Rp10,800 triliun dan } \\
\text { sudah diterima } 9 \text { juta penerima manfaat }\end{array}$ \\
\hline 6 & $\begin{array}{l}\text { Program Bansos Tunai di } \\
\text { luar Jabodetabek }\end{array}$ & $\begin{array}{l}\text { Pengembangan program } \\
\text { bantuan sosial dengan } \\
\text { pelibatan pemerintah } \\
\text { daerah }\end{array}$ & $\begin{array}{l}\text { - Program baru } \\
\text { - Telah tersalurkan Rp24,787 triliun dan } \\
\text { sudah diterima 9,1 juta penerima } \\
\text { manfaat }\end{array}$ \\
\hline 7 & Program Kartu Prakerja & $\begin{array}{l}\text { Perluasan Sistem Jaminan } \\
\text { Sosial }\end{array}$ & $\begin{array}{l}\text { - Target } 5.6 \text { juta penerima manfaat } \\
\text { - Telah tersalurkan Rp } 16,617 \text { triliun dan } \\
\text { sudah diterima oleh } 4,8 \text { juta penerima } \\
\text { manfaat }\end{array}$ \\
\hline 8 & $\begin{array}{l}\text { Program Banpres } \\
\text { Produktif untuk Modal } \\
\text { Kerja }\end{array}$ & $\begin{array}{l}\text { Perluasan Sistem Jaminan } \\
\text { Sosial }\end{array}$ & $\begin{array}{l}\text { - Program Banpres } \\
\text { - Telah tersalurkan Rp14,183 triliun untuk } \\
\text { diterima 5,9 juta penerima manfaat yaitu } \\
\text { UMKM }\end{array}$ \\
\hline 9 & Program BLT Dana Desa & $\begin{array}{l}\text { Pengembangan program } \\
\text { bantuan sosial dengan } \\
\text { pelibatan pemerintah } \\
\text { daerah }\end{array}$ & $\begin{array}{l}\text { - Telah tersalurkan Rp } 11,730 \text { triliun dan } \\
\text { sudah diterima } 7,55 \text { juta penerima } \\
\text { manfaat }\end{array}$ \\
\hline
\end{tabular}

Sumber: Data olahan penulis berdasarkan publikasi Setkab (September 2020) dan World Bank (Juni 2020)
Keluarga Harapan (PKH) yang ditingkatkan hingga 25\%, serta mekanisme penyalurannya diubah dari triwulan menjadi setiap bulan selama pandemi (Purwanto, 2021).

Patut dicermati bahwa menurut data yang diolah World Bank (2019) belanja pemerintah Indonesia sampai dengan tahun 2018 untuk program bantuan sosial, tidak termasuk subsidi, telah meningkat lebih dari dua kali lipat secara riil antara tahun 2009 dan 2018. Peningkatan belanja tersebut mencerminkan peningkatan cakupan yang sangat besar, dengan program PKH dan PIP melipatgandakan jumlah penerima manfaat antara 2010 dan 2017. Namun, total anggaran belanja untuk bantuan sosial di luar subsidi tetap rendah pada kisaran 0,7\% dari PDB Indonesia. Porsi pemerintah Indonesia untuk belanja program bantuan sosial dapat dikategorikan rendah bila dibandingkan dengan ratarata alokasi bantuan sosial negara berpenghasilan menengah ke bawah secara global. Di wilayah Asia Timur dan Pasifik, alokasi bantuan sosial Indonesia setara dengan negara-negara seperti Vietnam, Thailand dan Malaysia, meski lebih rendah dari mayoritas negara di wilayah Amerika Latin dan Eropa Timur, serta Asia Tengah (World Bank, 2019).

Pemerintah menyadari penguatan sistem perlindungan sosial serta perluasan penyaluran bantuan sosial sesegera mungkin sebagai respons pandemi adalah penyelamat utama daya beli masyarakat. Hal ini didukung oleh penelitian bahwa tanpa adanya bantuan sosial darurat dari pemerintah, pandemi Covid-19 akan mendorong 5,5 sampai dengan 8 juta penduduk Indonesia ke jurang kemiskinan (World Bank, 2020a). Sebagai bagian dari respons cepat krisis Covid-19, tidak hanya pemerintah telah mengimplementasikan paket fiskal darurat setara dengan 3,8\% PDB tahun 2020 (belanja aktual) dan 4,2\% PDB tahun 2021 (per 18 Maret 2021) untuk menangani dampak kesehatan, bantuan untuk rumah tangga 
dan usaha, serta mendukung upaya vaksinasi dan pemulihan (World Bank, 2020b).

Sistem perlindungan sosial yang komprehensif, dikelola dengan baik, tepat sasaran, dan mudah dimodifikasi atau adaptif sangat penting untuk menghadapi dampak akibat krisis Covid-19 (Olivia dkk., 2020, hlm. 166). Program bantuan sosial harus dapat diperluas secara horizontal agar dapat menjangkau penerima manfaat yang baru terkena dampak krisis, serta secara vertikal untuk melindungi penerima manfaat yang lama, yang mungkin menjadi lebih miskin hingga membutuhkan peningkatan manfaat bantuan sosial pada saat dibutuhkan. Sedangkan, kombinasi strategi dalam penyaluran bantuan sosial di saat krisis menurut (Gerard dkk., 2020, hlm. S282) dapat mengoptimalkan jaring pengaman sosial di negara berpenghasilan menengah dan rendah dengan cakupan yang lebih luas dan lebih berdampak. Strategi kombinasi perlindungan sosial ini dapat mencakup:

1. memperluas sistem jaminan sosial;

2. mengembangkan program bantuan sosial yang telah berjalan, menjangkau lebih banyak rumah tangga rentan yang terdampak; dan

3. melibatkan pemerintah daerah dan lembaga non pemerintah untuk mengidentifikasi dan menjangkau kelompok rentan yang mungkin tidak terjangkau oleh nomor 1 dan nomor 2.

Hal ini sejalan dengan hasil penelitian serupa yang menyebutkan bahwa strategi kombinasi perluasan jaminan sosial, pengembangan program bantuan sosial yang telah berjalan, serta pelibatan berbagai pemangku kepentingan (stakeholder) baik pemerintah lokal mau pun non-pemerintah dalam menghadapi krisis merupakan strategi yang kerap diterapkan di negara-negara Asia Timur seperti Jepang, Korea Selatan, dan Taiwan, ketika menghadapi krisis ekonomi (Soon dkk., 2021, hlm. 233-234). Berbekal pengalaman menghadapi krisis ekonomi tahun 1998, pandemi SARS serta MERS, Indonesia telah memiliki modal untuk menghadapi krisis Covid-19. Basis data terpadu Indonesia (sekarang Data Terpadu Kesejahteraan Sosial/DTKS) yang berisi data sosial ekonomi $40 \%$ rumah tangga termiskin di Indonesia telah ditingkatkan dari sejak krisis ekonomi 1998, kini digunakan untuk mengidentifikasi kelompok penerima manfaat (Olivia dkk., 2020, hlm. 166). Meskipun hal pembatasan 40\% rumah tangga termiskin dalam DTKS ini juga dapat menghalangi identifikasi penerima manfaat bantuan sosial di masyarakat yang terdampak Covid-19 (Holmemo dkk., 2020, hlm. 197).

Semua strategi perluasan perlindungan sosial berupaya diterapkan oleh pemerintah Indonesia dalam respons penanggulangan pandemi Covid-19 (Tabel 2). Selain meluncurkan program baru seperti BLT Dana Desa yang melibatkan pemerintah daerah dan Subsidi Gaji/Upah sebagai respons pandemi Covid-19, Indonesia juga berupaya menurunkan beban pengeluaran rumah tangga melalui perluasan kesertaan PKH dan program Sembako, khususnya untuk memenuhi kebutuhan pangan dan peningkatan gizi masyarakat. World Bank (2020b, hlm. 77-78) menilai bahwa strategi yang diambil pemerintah untuk mengurangi dampak pandemi terhadap masyarakat miskin di Indonesia telah mencakup kombinasi perluasan bantuan sosial, pengembangan program bantuan sosial yang sudah ada, penambahan program bantuan sosial yang baru, dan penataan ulang program bantuan sosial.

Meski krisis Covid-19 membawa krisis multidimensi yang membuat Indonesia terus mengembangkan ragam program perlindungan sosial, Indonesia tidak lantas menerapkan semua jenis perlindungan sosial. Universal Basic Income (UBI) atau Jaminan Pendapatan Semesta/Jamesta, yaitu program perlindungan sosial di mana pemerintah memberikan bantuan tunai pada individu sebagai solusi pengentasan kemiskinan belum diterapkan di Indonesia (Maftuchan dkk., 2020, hlm. 6-7) karena keraguan terkait kapasitas fiskal pemerintah Indonesia untuk mengakomodasi kebijakan ini. Namun demikian, untuk pertama kalinya pemerintah Indonesia menerapkan program terbatas subsidi upah atau gaji di tahun 2020 sebagai bagian dari respons pandemi Covid-19. Peneliti memandang bahwa Indonesia perlu kembali mempertimbangkan opsi penerapan UBI dan program bantuan sosial komprehensif lainnya di Indonesia mengingat setidaknya 27 penelitian terbaru mengenai dampak dari penerapan UBI di berbagai negara di dunia menemukan manfaat kesehatan berupa menurunnya mortalitas serta meningkatnya pemberian nutrisi bagi bayi berat badan lahir rendah/low birthweight infants dan kesehatan mental (Gibson dkk., 2020) serta hasil survei masyarakat yang menyatakan keterbukaan mereka atas penerapan program perlindungan sosial yang lebih progresif seperti UBI/Jamesta, jaminan pekerjaan, dan jaminan pengangguran (Maftuchan dkk., 2020, hlm. 41).

Untuk mendukung kebijakan perlindungan sosial di masa pandemi, Indonesia juga mengambil kebijakan fiskal dengan melakukan revisi peraturan perundang-undangan untuk melebarkan defisit anggaran 2020 menjadi 5,07\%, kemudian melebar kembali ke level 6,27\%, lalu menjadi 6,34\% terhadap PDB untuk mengakomodasi kenaikan belanja negara untuk penanggulangan pandemi Covid-19, salah satunya bantuan sosial, yang terus bertambah (Silalahi \& Ginting, 2020). Langkah pelebaran defisit APBN ini dilakukan dengan merevisi Peraturan Presiden Nomor 54 Tahun 2020 dan Peraturan Presiden Nomor 72 Tahun 2020 terkait Perubahan Postur dan Rincian Anggaran Pendapatan dan Belanja Negara Tahun Anggaran 2020. Semua peraturan perundangundangan ini memberikan pengecualian atas ketentuan dalam Undang-Undang Nomor 17 Tahun 2003 tentang Keuangan Negara yang menyebutkan defisit anggaran dibatasi maksimal $3 \%$ dari PDB.

Pelebaran defisit sebagai respons atas pandemi Covid-19 ini merupakan defisit anggaran terbesar yang pernah dialami Indonesia sejak diterbitkannya UU Nomor 17 Tahun 2003 yang membatasi defisit anggaran minimal 3\%. Indonesia juga mengalami lonjakan defisit anggaran pada krisis moneter 
tahun 1999, menembus angka 6,8\% dari PDB pada tahun 1998 dan sebesar 4,5\% dari PDB pada tahun 2000 karena melemahnya nilai tukar rupiah terhadap dolar (Departemen Keuangan Republik Indonesia, 1999). Pada tahun 2008, kembali terjadi krisis yang disebabkan oleh kenaikan harga minyak dan komoditi pangan dunia yang diikuti oleh krisis di pasar keuangan internasional, serta perlambatan pertumbuhan ekonomi dunia yang menyebabkan Indonesia mengalami defisit anggaran namun hanya sebesar 2,1\% dari PDB. Lebarnya defisit anggaran saat ini karena krisis pandemi Covid-19 banyak dipengaruhi oleh belanja agresif pemerintah untuk bantuan sosial dan penanganan pandemi Covid-19 bila dibandingkan dengan krisis-krisis sebelumnya.

Peningkatan belanja negara yang dicanangkan untuk meningkatkan bantuan sosial telah terserap dengan cukup baik. Penyerapan anggaran merupakan salah satu tolok ukur kinerja pemerintah dalam menggerakkan roda perekonomian hal ini disebabkan karena belanja pemerintah menjadi pendorong utama laju pertumbuhan ekonomi. Semakin awal pelaksanaan kegiatannya akan memberikan manfaat dan efek stimulus yang besar bagi kepentingan masyarakat. Jika pelaksanaan kegiatan mundur ke akhir tahun karena beberapa faktor padahal seharusnya dilaksanakan lebih awal, maka yang dirugikan adalah masyarakat karena masyarakat tertunda menerima manfaat (Dewi dkk., 2017, hlm. 1625). Dalam konteks perlindungan sosial yang diberikan oleh negara, hal ini dapat berarti tidak tersalurkannya bantuan sosial kepada kalangan masyarakat yang membutuhkan. Data dari Kementerian Sosial, untuk enam program bantuan sosial yang telah dianggarkan sebagai respons penanggulangan pandemi Covid-19 (PKH, BNPT, Bansos Sembako Jabodetabek, Bansos Tunai, Bansos Beras, dan Bansos Tunai bagi KPM Sembako non-PKH) telah terserap 99,8\% dari alokasi pagu Rp129 triliun pada akhir tahun 2020. Selanjutnya data sampai dengan Mei 2021 menunjukkan penyerapan tiga program bantuan sosial; PKH, BPNT/Kartu Sembako, dan Bansos Tunai/BST sampai dengan Mei 2021 penyerapan telah mencapai 43,44\% yaitu sebesar Rp37 triliun.

Sejak Juli 2020, berbagai program perlindungan sosial sebagai respons pandemi Covid-19 kemudian diintegrasikan dalam Program Pemulihan Ekonomi Sosial (PEN) yang diluncurkan oleh Presiden Joko Widodo. Tujuan dari integrasi program perlindungan sosial dengan program penanganan kesehatan masyarakat adalah agar dapat berjalan dengan selaras agar penanganan kesehatan masyarakat terlindungi dari dampak pandemi Covid-19, seiring dengan upaya menjaga pertumbuhan ekonomi Indonesia. Selama ini terdapat asumsi bahwa kebijakan terkait intervensi kesehatan masyarakat dan pemulihan ekonomi tidak sejalan. Pemerintah sering kali mengalami dilema ketika kedua kebijakan ini dipertentangkan. Sebagai contoh, durasi lockdown dan pengaturan mobilitas masyarakat yang diterapkan untuk mencegah penyebaran Covid-19 berpengaruh pada pemasukan rumah tangga terdampak yang juga akan menentukan seberapa besar jangkauan program perlindungan sosial yang akan diberikan.
Namun, menurut penelitian Hasell (2020) mengenai dampak intervensi kebijakan kesehatan publik dan kebijakan ekonomi saat pandemi di berbagai negara, hasil yang ditemukan justru sebaliknya. Dengan membandingkan angka kematian akibat Covid-19 dengan data PDB terbaru, dapat disimpulkan bahwa negara-negara yang kebijakannya berhasil melindungi kesehatan penduduknya saat pandemi pada umumnya juga berhasil melindungi perekonomiannya.

Namun demikian, tingkat kecepatan penyerapan anggaran keseluruhan program penanggulangan dampak Covid-19 di bawah payung PEN masih perlu ditingkatkan. Bila dibandingkan dengan angka penyerapan anggaran perlindungan sosial pada tahun 2020-2021. Besaran anggaran PEN pada tahun 2020 mencapai Rp695,2 triliun, namun serapan anggaran PEN masih di bawah 30\% per Agustus 2020 dan pada akhir tahun 2020, realisasi sementara mencapai Rp579,8 triliun, atau 83,4\%. Sedangkan pada tahun 2021, realisasi anggaran PEN 2021 baru mencapai Rp155,6 triliun atau setara 22,3\% pagu sampai dengan 30 April 2021.

Dalam masa krisis akibat pandemi Covid-19, berbagai komponen pembentuk permintaan agregat (aggregate demand) di banyak negara juga merosot, baik konsumsi, investasi, begitu juga dengan ekspor dan impor. Dalam kondisi seperti ini, anggaran negara menjadi instrumen utama untuk menggerakkan roda perekonomian dan meredam dampak krisis terhadap masyarakat. Dalam kondisi resesi ekonomi, intervensi pemerintah melalui belanja negara efektif dalam menangani krisis. Dalam kondisi krisis, belanja negara atau government spending menjadi salah satu ujung tombak pemulihan permintaan dan alat stabilisasi ekonomi. Kegagalan atau keterlambatan target penyerapan anggaran dapat mengindikasikan telah terjadinya inefisiensi dan inefektivitas pengalokasian anggaran. Menanggapi pandemi Covid-19, para pembuat kebijakan di seluruh dunia telah memperkenalkan tingkat stimulus fiskal yang belum pernah terjadi sebelumnya, dengan total nilai yang melebihi 10\% dari PDB global. Meskipun menurut analisis terbaru dari PBB, langkah-langkah stimulus ini mungkin tidak meningkatkan konsumsi dan investasi sejauh atau secepat yang diharapkan karena pembatasan kegiatan ekonomi selama lockdown (Olivia dkk., 2020, hlm. 169).

Holmemo dkk. (2020, hlm. 2) menekankan bahwa Indonesia masih perlu memaksimalkan penyaluran programprogram perlindungan sosial, salah satunya dengan melakukan investasi dalam sistem-sistem untuk identifikasi, penargetan, dan pembayaran program perlindungan sosial. Dalam kaitannya dengan penanganan krisis Covid-19, negara-negara yang mampu merespons dengan cepat adalah negara yang memiliki data sosial terpadu untuk identifikasi penduduk yang menghadapi guncangan mata pencarian. Hal ini selaras dengan hasil survei-survei masyarakat di tahun 2020 juga menandai kurangnya kepercayaan publik atas kemampuan pemerintah untuk mengelola bantuan sosial secara efisien dari sisi anggaran serta dalam menjangkau masyarakat miskin secara tepat sasaran. Sekitar 70,2\% responden survei yang dilakukan CSO 
Prakarsa menyatakan bahwa bantuan sosial pemerintah selama pandemi Covid-19 ini masih belum efektif menjangkau masyarakat atau rumah tangga miskin, sementara hanya 36,6\% responden yang mengikuti survei dari INFID, KPI dan IndoBIG Network pada bulan Mei tahun 2020 menyatakan program bantuan sosial sudah sesuai dengan kebutuhan mereka (Maftuchan dkk., 2020, hlm. 35-36). Permasalahan penyaluran yang bersumber dari basis data bagi penerima manfaat program perlindungan sosial merupakan masalah klasik yang terus menerus dibenahi di Indonesia dengan upaya penerapan data satu pintu (Habibullah, 2017, hlm. 11-12).

Di era pandemi Covid-19, bukan hanya peningkatan peran welfare state dalam menangani pandemi dengan memperluas sistem perlindungan sosial dan pemulihan ekonomi nasional yang mendapatkan relevansi baru tetapi juga peran teknologi dalam sistem perlindungan sosial tersebut sebagai strategi jangka panjang penyaluran perlindungan sosial. Pandemi Covid-19 memaksa berbagai negara menerapkan strategi kombinasi multiguna untuk menjangkau lebih banyak kelompok rentan dan masyarakat miskin, serta juga mengembangkan mekanisme distribusi baru untuk penyaluran bantuan sosial dengan bantuan teknologi/etransfer untuk mengatasi pembatasan pergerakan karena pandemi Covid-19 (Abdoul-Azize \& El Gamil, 2021, hlm. 114). Fenomena teknologi dan big data sebagai bagian dari strategi penanganan atas pandemi Covid-19 ini menimbulkan apa yang disebut sebagai 'negara kesejahteraan digital'/digital welfare state di mana pemerintah bermitra dengan perusahaan penyedia teknologi bermitra untuk membentuk infrastruktur baru dalam berbagai aspek mulai dari kesehatan, pendidikan, penyaluran bantuan sosial, dan pendataan pekerja (Dencik \& Kaun, 2020). Indonesia juga telah mempertimbangkan opsi ini dengan merencanakan kerja sama dengan perusahaan fintech yang khusus memberikan layanan sistem pembayaran dan uang elektronik untuk penyaluran bantuan sosial (Rini, 2020). Pemerintah merencanakan digitalisasi data bansos yang terintegrasi dengan sistem perbankan agar 110 triliun dana bansos dapat disalurkan secara digital ke rekening penerima manfaat atau melalui jaringan pos agar lebih tepat sasaran (Aria, 2020). Strategi integrasi, digitalisasi bantuan sosial, dan penguatan mekanisme bantuan sosial nontunai yang mempermudah masyarakat miskin ini telah dituangkan dalam pemerintah dalam Perpres 122/2020 tentang Pemutakhiran RKP 2021 yang memuat percepatan penanggulangan kemiskinan sebagai dampak pandemi Covid-19. Untuk mencapai keseimbangan yang baik antara perlindungan kesehatan, pemulihan ekonomi dan pemenuhan kebutuhan kesejahteraan di masa pandemi Covid-19, pemerintah harus terus bekerja sama dengan pasar, komunitas, keluarga, individu, dan masyarakat global.

\section{Kesimpulan}

Di masa pandemi Covid-19, peran Indonesia sebagai welfare state telah mendapatkan relevansi baru karena kekhususan karakteristik Covid-19 yang berbeda dari krisis-krisis lainnya. Kekhususan pandemi Covid-19 yaitu ia merupakan krisis yang terjadi dalam skala global, menimpa negara maju maupun berkembang, melibatkan banyak dimensi baik kesehatan masyarakat serta ekonomi, juga banyak bersinggungan dengan teknologi karena adanya pembatasan sosial dalam beragam skala. Indonesia sebagaimana juga banyak negara pada masa krisis Covid-19 ini telah meningkatkan keterlibatan dan mengambil tanggung jawab lebih besar untuk menjamin kesejahteraan masyarakatnya lebih dari sebelum terjadinya pandemi. Langkah-langkah yang diambil pemerintah terhadap masyarakat miskin di Indonesia telah mencakup kombinasi strategi perluasan bantuan sosial melalui $\mathrm{PKH}$, pengembangan program bantuan sosial yang sudah ada, penambahan program-program bantuan sosial yang baru (Subsidi Upah dan Subsidi Tarif Listrik), dan penataan ulang program bantuan sosial dengan pelibatan pemerintah daerah dan institusi non pemerintah (BLT Dana Desa), serta kebijakan fiskal lainnya seperti pelebaran defisit pemerintah. Meskipun Indonesia telah mengerahkan banyak cara untuk mengatasi dampak krisis dari pandemi Covid-19, tetap diperlukan upaya tambahan untuk meningkatkan efektivitas dan efisiensi sistem perlindungan sosial dengan mempertimbangkan kekhususan karakter pandemi Covid-19 yang masih berlangsung hingga membutuhkan strategi jangka panjang. Pengembangan strategi jangka panjang ini dapat mencakup pemantauan penyerapan anggaran belanja pemerintah agar lebih terukur dan tersalurkan, penerapan UBI atau skema perlindungan sosial lain yang lebih progresif, serta pemutakhiran dan digitalisasi basis data penerima manfaat perlindungan sosial melalui kemitraan berkelanjutan dengan swasta adalah beberapa opsi yang patut dipertimbangkan. Terakhir, masih diperlukan penelitian lebih mendalam mengenai respons welfare state di era krisis Covid-19 karena hingga saat ini banyak negara masih terus mencari pendekatan/model yang paling sesuai untuk mengelola lingkungan sosial, ekonomi dan politik mereka yang terus berubah karena pandemi Covid-19.

\section{Ucapan Terima Kasih}

Penulis mengucapkan terima kasih kepada Kepala Biro Perencanaan dan Kerja Sama Kemenko PMK atas motivasinya untuk menyelesaikan tulisan ini serta pihak-pihak yang telah memberikan saran masukan bagi penyempurnaan tulisan ini.

\section{Referensi}

Abdoul-Azize, H. T., \& El Gamil, R. (2021). Social Protection as a Key Tool in Crisis Management: Learnt Lessons from the COVID-19 Pandemic. Global Social Welfare, 8(1), 107-116. https://doi.org/10.1007/ s40609-020-00190-4

Aria, P. (2020, Desember 30). Ma'ruf Amin: Rp 110 Triliun Bansos 2021 Disalurkan secara Digital. katadata.co.id. https://katadata.co.id/ pingitaria/berita/5febeb1 cd7903/maruf-amin-rp-110-triliunbansos-2021-disalurkan-secara-digital

Barr, N. A. (2020). The Economics of the Welfare State (Sixth Edition). Oxford University Press.

Breznau, N. (2021). The welfare state and risk perceptions: The Novel Coronavirus Pandemic and public concern in 70 countries. European $\begin{array}{llll}\text { Societies, 23(sup1), S33-S46. } & \text { https://doi.org/ }\end{array}$ 10.1080/14616696.2020.1793215 
Carli, L. L. (2020). Women, Gender equality and COVID-19. Gender in Management: An International Journal, 35(7/8), 647-655. https:// doi.org/10.1108/GM-07-2020-0236

Christos, I., Areti, T., Konstantinos, K., \& Lambrini, K. (2019). Theories of Supply and Demand, Problems and Peculiarities in the Healthcare Sector: Its Effects on Health Policy. Journal of Healthcare Communications, 4(3), 1-5. https://doi.org/ 10.36648/2472-1654.4.3.155

Creswell, J. W., Goodchild, L. F., \& Turner, P. P. (1996). Integrated Qualitative and Quantitative Research: Epistemology, History, and Designs. Dalam J. C. Smart (Ed.), Higher Education: Handbook of Theory and Research (Vol. 11, hlm. 90-136). Springer Netherlands.

Dencik, L., \& Kaun, A. (2020). Datafication and the Welfare State. Global Perspectives, 1(1), 12912. https://doi.org/10.1525/gp.2020.12912

Departemen Keuangan Republik Indonesia. (1999). Nota Keuangan dan RAPBN Tahun 1999/2000. Dalam Kemenkeu. Departemen Keuangan Republik Indonesia.

Department of Economic and Social Affairs. (2020). World Social Report 2020: Inequality in a Rapidly Changing World. United Nations.

Dewi, N. L. P. L., Dwirandra, A. A. N. B., \& Wirakusuma, M. G. (2017) Kemampuan Komitmen Organisasi Memoderasi Pengaruh Perencanaan Anggaran dan Kompetensi SDM pada Penyerapan Anggaran Pemerintah Kabupaten Tabanan. E-Jurnal Ekonomi dan Bisnis Universitas Udayana, 6(4), 1609-1638. https://ojs.unud.ac.id/ index.php/EEB/article/view/25404

Gentilini, U Almenfi, M., Orton, I., \& Dale, P (2020). Social Protection and Jobs Responses to COVID-19: A Real-Time Review of Country Measures. World Bank. http://hdl.handle.net/10986/33635

Gerard, F., Imbert, C., \& Orkin, K. (2020). Social protection response to the COVID-19 crisis: Options for developing countries. Oxford Review of Economic Policy, 36(Supplement_1), S281-S296. https://doi.org/ 10.1093/oxrep/graa026

Gibson, M., Hearty, W., \& Craig, P. (2020). The public health effects of interventions similar to basic income: A scoping review. The Lancet Public Health, 5(3), e165-e176. https://doi.org/10.1016/ S2468-2667(20)30005-0

Habibullah. (2017). Perlindungan Sosial Komprehensif di Indonesia. Sosio Informa, 3(1), 1-14. https://doi.org/10.33007/inf.v3i1.492

Hasell, J. (2020, September 1). Which countries have protected both health and the economy in the pandemic? Our World in Data. https:// ourworldindata.org/covid-health-economy

Holmemo, C., Acosta, P., George, T., Palacios, R. J., Pinxten, J., Sen, S., \& Tiwari, S. (2020). Investing in People: Social Protection for Indonesia's 2045 Vision. World Bank. http://hdl.handle.net/10986/33767

Iping, B. (2020). Perlindungan Sosial Melalui Kebijakan Program Bantuan Langsung Tunai (BLT) di Era Pandemi Covid-19: Tinjauan Perspektif Ekonomi dan Sosial. Jurnal Manajemen Pendidikan dan IImu Sosial, 1(2), 516-526. https://doi.org/10.38035/jmpis.v1i2.290

Maftuchan, A. H., Pertiwi, A. T., Afrina, E., Ramdlaningrum, H., Bahagijo, S., \& Prasetyo, Y. (2020). Universal Basic Income (No. 2). Perkumpulan Prakarsa. http://theprakarsa.org/prakarsa-working-paper-02-universalbasic-income/

Morlino, L., \& Raniolo, F. (2017). The Impact of the Economic Crisis on South European Democracies. Springer International Publishing. https:// doi.org/10.1007/978-3-319-52371-2
Olivia, S., Gibson, J., \& Nasrudin, R. (2020). Indonesia in the Time of Covid19. Bulletin of Indonesian Economic Studies, 56(2), 143-174. https:/ doi.org/10.1080/00074918.2020.1798581

Patel, S. B., \& Kariel, J. (2021). Universal basic income and covid-19 pandemic. BMJ, 1-2. https://doi.org/10.1136/bmj.n193

Purwanto, A. (2021, Maret 15). Kemiskinan pada Masa Pandemi Covid-19: Konsep, Potret, dan Strategi Pengentasan. Kompaspedia. https:// kompaspedia.kompas.id/baca/paparan-topik/kemiskinan-pada-masapandemi-covid-19-konsep-potret-dan-strategi-pengentasan

Rini, A. S. (2020, Mei 20). Perusahaan Fintech Berkomitmen Dukung Penyaluran Bansos Pemerintah. Bisnis.com. https:// finansial.bisnis.com/read/20200520/563/1243305/perusahaan-fintechberkomitmen-dukung-penyaluran-bansos-pemerintah

Silalahi, D. E., \& Ginting, R. R. (2020). Strategi Kebijakan Fiskal Pemerintah Indonesia untuk Mengatur Penerimaan dan Pengeluaran Negara dalam Menghadapi Pandemi Covid-19. Jesya (Jurnal Ekonomi \& Ekonomi Syariah), 3(2), 156-167. https://doi.org/10.36778/ jesya.v3i2.193

Soon, S., Chou, C. C., \& Shi, S. (2021). Withstanding the plague: Institutional resilience of the East Asian welfare state. Social Policy \& Administration, 55(2), 374-387. https://doi.org/10.1111/spol.12713

Suharto, E. (2011). Kebijakan Sosial. Alfabeta.

Sumarto, M. (2017). Welfare Regime Change in Developing Countries: Evidence from Indonesia. Social Policy and Administration, 51(6), 940 959. https://doi.org/10.1111/spol.12340

Suryahadi, A., Al Izzati, R., \& Suryadarma, D. (2020). Estimating the Impact of Covid-19 on Poverty in Indonesia. Bulletin of Indonesian Economic Studies, 56(2), 175-192. https://doi.org/ 10.1080/00074918.2020.1779390

Uluwiyah, A. (2018). Analisis Capaian Kesejahteraan Masyarakat Dikaitkan dengan Anggaran Belanja Pemerintah Menggunakan Analisis Regresi. Jurnal Penelitian Kesejahteraan Sosial, 17(4), 309-318. https:// ejournal.kemsos.go.id/index.php/jpks/article/view/1575

Wincott, D. (2001). Reassessing the Social Foundations of Welfare (State) Regimes. New Political Economy, 6(3), 409-425. https://doi.org/ 10.1080/13563460120091405

World Bank. (2019). Indonesia Economic Quarterly, December 2019 Investing in People (hlm. 1-67). World Bank. http://hdl.handle.net/ 10986/33033

World Bank. (2020a). Prospek Ekonomi Indonesia, Juli 2020: Jalan Panjang Pemulihan Ekonomi. https://www.worldbank.org/in/country/indonesia/ publication/july-2020-indonesia-economic-prospect

World Bank. (2020b, Mei 29). The World Bank Approves Financing for Indonesia's COVID-19 Emergency Response [Press Release]. The World Bank. https://www.worldbank.org/en/news/press-release/ 2020/05/29/the-world-bank-approves-financing-for-indonesiascovid-19-coronavirus-emergency-response

World Bank. (2020c, Oktober 7). COVID-19 to Add as Many as 150 Million Extreme Poor by 2021 [Press Release]. World Bank. https:// www.worldbank.org/en/news/press-release/2020/10/07/covid-19-toadd-as-many-as-150-million-extreme-poor-by-2021 